\title{
Capital Controls, Political Institutions, and Economic Growth: A Panel and Cross Country Analysis*
}

\author{
Shanker Satyanath and Daniel Berger \\ Nem York University, Nem York, NY 10012, USA
}

\begin{abstract}
Statistical studies on the effects of capital controls on growth have generally yielded insignificant results. In this paper, we show that capital controls negatively affect growth in authoritarian countries, while growth in democratic countries is insignificantly affected. We also show that the adverse effects of capital controls likely pass through the efficiency of investment. Our findings suggest that policy makers should take careful account of the political context when considering the decision to impose capital controls.
\end{abstract}

Do controls on cross border capital flows depress economic growth? Recent events suggest that the answer to this question is not straightforward. Countries with extensive capital controls have displayed a wide range of growth rates, the difference between the economic performances of China and most African nations being a case in point. Similar differences have been observed for countries operating under liberal capital flows. For instance, some developing countries with limited capital controls experienced years of slow growth following currency turmoil in the late 1990s while others experienced rapid recoveries. ${ }^{1}$ The case study literature suggests a role for political institutions in accounting for some of these variations in outcomes. ${ }^{2}$ However, the question of whether the relationship between capital controls and growth differs across political institu-

* We would like to thank Jeff Frieden, Dennis Quinn, Bill Clark, and seminar participants at Duke University, UCLA, University of Minnesota, and Columbia University for their wise comments. Special thanks also for an exceptionally insightful and conscientious anonymous reviewer.

1 See the extensive case literature on the East Asian financial crisis.

2 For instance, see MacIntyre (2002).

MS submitted 20 September 2006; final version received 25 fuly 2007

ISSN 1554-0626; DOI 10.1561/100.00006044

C) 2007 S. Satyanath and D. Berger 
tional environments has not received systematic attention in a large- $n$ context. In this paper, we show that the relationship between capital controls and growth varies substantially depending on whether democratic or authoritarian institutions are present. We demonstrate a significant negative relationship between capital controls and growth in authoritarian environments. On the other hand we show that capital controls have an insignificant effect on growth in democracies. We also show that the adverse effects of capital controls likely pass through the efficiency of investment. Our findings suggest that policy makers should take careful account of the political context when considering the decision to impose capital controls.

The introduction of political institutions into the debate over the growth effects of capital controls is useful because it resolves some of the ambiguity in the capital controls and growth literature in Economics. Previous empirical literature either indicates no relationship between capital controls and growth (Alesina et al. 1994, Rodrik 1998, Eichengreen and Leblang 2003) or generates mutually contradictory results (Quinn 1997, Arteta et al. 2001, Edwards 2001, Edison et al. 2002). Our paper resolves some of the ambiguity in this literature by highlighting the neglected political economy dimension of this relationship.

\section{EMPIRICAL STRATEGY AND DATA}

While we lead off with some standard cross country growth regressions, our core analysis is based on panel data using six non overlapping five year periods, starting from 1970. We choose to rely more on panel analysis thanks to the concerns about the robustness of results emerging from cross country growth regressions that have been expressed in many recent contributions to the literature (beginning with Levine and Renelt 1992). ${ }^{3}$ Our dependent variable is the growth of average per capita GDP between successive five year periods, and we accordingly average values of right hand side variables over five year periods as well. We average over five years rather than use the country year as the unit due to the extreme instability and volatility of annual GDP data. Pritchett (2000) is the standard source referred to by economists for why averaging constitutes best practice for growth regressions. As Pritchett puts it, "given the instability and volatility of output, moving to shorter and shorter time periods and eliminating long period variance are likely to entangle dynamics, specification, endogeneity, and statistical power, which will ultimately confuse, not clarify, issues of growth, especially in developing countries." 4

3 Cross country regressions, of course, generate a high degree of vulnerability to omitted variables bias.

4 Pritchett (2000, p. 235) Pritchett is especially eloquent on the problem of dynamic misspecification that results from using periods as short as a year. In his words, "arbitrarily parsing time series into shorter periods imposes the assumption that the dynamics are invariant across growth correlates...In fact although some growth effects are contemporaneous, especially macroeconomic and cyclical factors, others could take several years, such as transitional dynamics due to changes in investment incentives, and still others could take decades, such as the impact of changes that could affect the rate of technical progress. Some right-hand side variables could have output or growth effects at all 
Our econometric specifications are based on the standard Solow growth model, which takes the following form:

$$
\log \mathrm{GDP}_{i, t}-\log \mathrm{GDP}_{i, t-1}=\phi_{t}+(\alpha-1) \log \mathrm{GDP}_{i, t-1}+x_{i, t}^{\prime} \beta+\eta_{i}+v_{i, t},
$$

where the $\phi_{t}$ are a complete set of period specific intercepts, $x_{i, t}$ is a vector of covariates of growth including capital controls, $\eta_{i}$ refers to country dummies, and $v_{i, t}$ refers to the error term. The lagged dependent variable is included to address convergence effects (which are a major feature of the Solow model), while the coefficient for lagged log of GDP is captured by $(\alpha-1)$ in order to address the presence of the same variable on the left hand side of the equation (as part of the growth calculation). The above model captures the growth effects of $x$ variables until the steady state growth rate is achieved, which is generally assumed to lie far in the future.

As may be easily seen Equation (1) is equivalent to

$$
\log \mathrm{GDP}_{i, t}=\phi_{t}+\alpha \log \mathrm{GDP}_{i, t-1}+x_{i, t}^{\prime} \beta+\eta_{i}+v_{i, t} .
$$

Since Equation (2) includes both the lagged dependent variable and country dummies on the right-hand side, and since this combination is known to generate Nickell bias which afflicts the lagged dependent variable and other right-hand side variables, we difference this equation to purge the country dummies and eliminate Nickell bias. ${ }^{5}$ (This is standard practice in growth regressions.) We address remaining endogeneity by instrumenting for differenced right-hand side variables using instrumental variables and GMM techniques. Standard errors are clustered by country.

Our measure of capital controls is the latest (and now widely considered to be the best) measure, developed by Chinn and Ito (2006). Chinn and Ito's measure is considered preferable to the other measures because it captures the intensity of controls, rather than simply indicating the presence or absence of controls. (The latter is a serious problem with the widely disseminated measure from the IMF.) For example, the Chinn and Ito measure takes account of evasion of capital control measures via current account transactions such as over/underinvoicing by taking account of restrictions on current account transactions when assessing the intensity of capital controls. The measure also takes account of the requirement of the surrender of export proceeds and the presence of multiple exchange rates, both of which generate constraints on moving capital across borders. By construction, the Chinn and Ito series takes a mean value of zero. While the original series decreases in value with an increase in controls we reverse this direction for ease of exposition. (See Chinn and Ito (2006) for further details.)

We use Przeworski and his colleagues' well known measure of democracy called REG (Alvarez et al. 2000). ${ }^{6}$ Across our various specifications we also use the major control

horizons-cyclical, transitional, and steady state and there is no reason to believe that these effects are of similar magnitude, nor have the same sign, because some policy choices may lead to temporary booms but ultimately to busts." (Note that this latter effect is widely considered to be a possibility when it comes to the liberalization of capital flows.)

5 See Nickell (1981).

6 The data is available at http://pantheon.yale.edu/ jac236/DATASETS.htm. 
variables used in the capital controls literature, namely, investment, inflation, schooling, life expectancy, per capita GDP, and trade openness (exports + imports divided by GDP). The data for all these variables is from GDNGD version $7 .{ }^{7}$ In our cross country specifications we also use the measure of ethnolinguistic fractionalization (ELF) provided by the Atlas Narodov Mira. The source is Easterly and Levine (1997). In our robustness checks we also control for currency crises, using the measure of speculative pressure provided by David Leblang (2003). We provide summary statistics in Table A.1.

\section{RESULTS}

We present our main results in Table 1 . Column 1 presents the results of a cross-sectional specification that employs all the controls that are widely used in the cross-sectional growth literature. The column shows that capital controls are not significantly associated with average growth over the period 1970-1999. In column 2, we allow for the effect of capital controls to be modified by the level of democracy. Row 1 of column 2 shows the effects of capital controls in authoritarian regimes. (We reverse Przeworski's coding scheme for ease of exposition, so a democracy is coded as 1 and an authoritarian regime as 0 .) Row 1 displays a negative relationship between capital controls and growth in authoritarian regimes. The relationship is significant at the $95 \%$ level. Row 3, which refers to the interaction term, shows that the presence of democracy significantly modifies this relationship in a positive direction. Manual calculation of the standard error for capital controls in democratic settings reveals that the positive relationship between controls and growth in democracies is significant at the $90 \%$ level (not shown). ${ }^{8}$ As we show below, the negative result for authoritarian regimes is robust across numerous robustness checks, while the positive result for democracies is not robust.

Having presented some indicative cross country results we now move to the results for our panel specifications with six five year periods. Columns 3 and 4 present the results of first differenced OLS specifications for authoritarian and democratic regimes, respectively. Democracies are countries with a score of 1 on our reversed REG scale in the preceding five year period, while authoritarian regimes are countries with scores of less than 1. (Since we are averaging annual observations to generate the democracy score for the five year period, a score of less than 1 indicates the presence of an authoritarian regime at some point in the previous five year period. In $75 \%$ of the cases countries were authoritarian for the entire five year period, while in $92 \%$ of the cases countries were authoritarian for more than half of the five year period.) This procedure generates roughly comparable sample sizes of democratic and authoritarian regimes, ensuring that differences in the significance of results across regimes are unlikely to be driven by differences in sample size.

7 GDNGD stands for Growth Development Network Growth Database. The data is available at http://www.nyu.edu/fas/institute/dri/.

8 See Brambor et al. (2005) for the formula. 


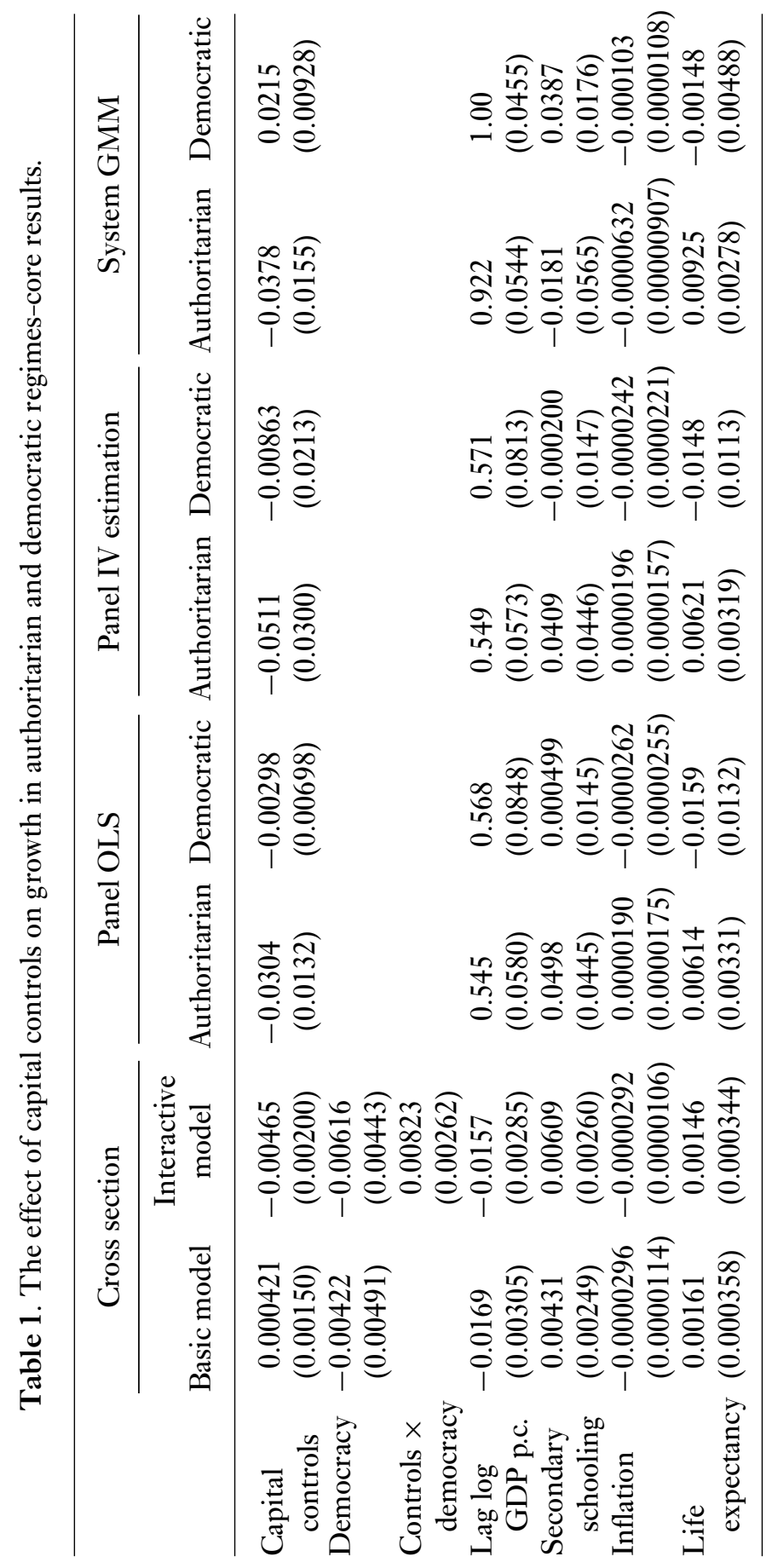




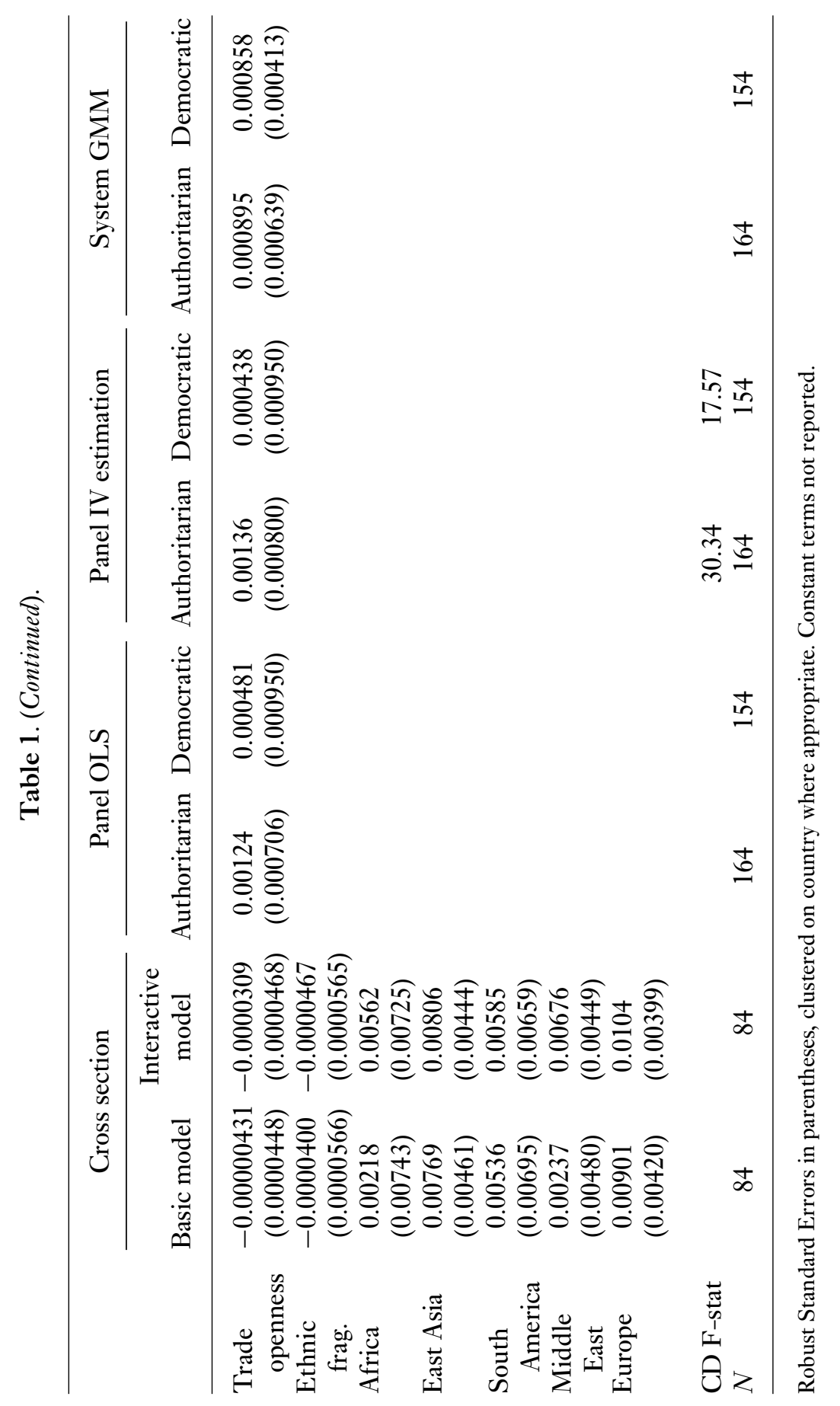


Column 3 indicates that capital controls are associated with significantly slower GDP growth in authoritarian environments. An increase in the intensity of capital controls of one standard deviation reduces growth in per capita GDP by approximately 2 percentage points in authoritarian regimes. ${ }^{9}$ Column 4 , on the other hand, indicates that capital controls are insignificantly associated with growth in democratic environments. The null hypothesis of no autocorrelation in the errors cannot be rejected in an Arellano and Bond test.

One potential concern with the above results is that capital controls are endogenous. For instance, slow (fast) growth may generate incentives to impose controls (liberalize). In columns 5 and 6 , we address these concerns by instrumenting for the first difference of capital controls with the second lag of the level of capital controls. The fact that the Cragg Donald F-statistic is well above the benchmark of 10 indicates that our instrumentation strategy does not suffer from a weak instruments problem. (See Table A.2 for first stage results.) Our instrumental variables regressions confirm the findings of our OLS analysis. Authoritarian regimes display a significant negative association between capital controls and growth (column 5) while democracies display an insignificant relationship (column 6).

The instrumental variables regressions described above do not address two sources of endogeneity, one emanating from the correlation between the differenced lagged dependent variable and the differenced error and the second resulting from the potential endogeneity of the control variables. In columns 7 and 8, we address the potential endogeneity of all right-hand side variables by using the Blundell and Bond system GMM estimator. ${ }^{10}$ This estimator is a relatively new version of the well known Arellano and Bond (1991) difference GMM estimator. Like Arellano and Bond, the Blundell and Bond estimator incorporates the lagged value of the dependent variable on the right-hand side. In addition to the equations in first differences found in Arellano and Bond, the Blundell and Bond estimator adds a set of equations in levels. Lagged levels of right-hand side variables are used as instruments for the differenced values of right-hand side variables, and lagged first differences are used as instruments for levels. (The differenced equations use all available lags of levels while the levels equations use the contemporaneous difference and all available lags.) In addition to the Arellano and Bond assumptions of serially uncorrelated transient errors and predetermined initial conditions, the Blundell and Bond estimator requires the identifying assumption that country specific effects are uncorrelated with the differenced values of the right-hand side variables. This assumption is reasonable conditional on the presence of time dummies to capture technological improvements that apply to all countries, as any correlation would imply that relative schooling rates, life expectancies, inflation, or trade openness are diverging over the long term which is implausible.

As columns 7 and 8 show, the Blundell and Bond system GMM estimator also shows that capital controls have a significant negative effect on growth in authoritarian regimes. However, democracies display a positive relationship between capital controls

9 The standard deviation of the first difference of capital controls for authoritarian regimes is 0.8 .

10 See Bond et al. (2001) for technical details. 
and growth. The null hypotheses of no $\mathrm{AR}(2)$ and fulfillment of the exclusion restriction cannot be rejected.

We can check whether the result for democracies is sensitive to the additional moment restrictions of Blundell and Bond by rerunning the above regressions with the Arellano and Bond estimator. The positive coefficient for democracy drops to insignificance confirming that this is not a robust result. On the other hand, the result for authoritarian regimes is robust to the application of the Arellano and Bond technique (see columns 1 and 2 in Table A.5).

So far we have established that there is a robust negative relationship between capital controls and growth in authoritarian regimes, but not in democracies. In Table 2, we address the question of why this difference may exist. Our basic procedure here is to assess major alternative causal stories via first differenced OLS regressions, instrumental variables regressions, and GMM techniques just as above. While we only present OLS regressions in the tables for reasons of space, we only accept a result in OLS as robust if it holds across most of the above specifications. (Results for instrumental variables and GMM estimates referred to below are presented in Tables A.3-A.5).

What causal path accounts for the results displayed in Table 1? Macroeconomic theory suggests that capital controls should have a negative effect on growth when they have a net depressing effect on investment. ${ }^{11}$ If this is the major chain of causation it is plausible that the difference between the growth effects of capital controls between regimes will disappear, or that the coefficient for capital controls will substantially change, when we additionally control for the level of investment. However, as column 1 of Table 2 shows, the coefficient for capital controls in authoritarian regimes hardly changes and remains significant. This result is robust to the use of both the Blundell and Bond and Arellano and Bond GMM estimators. (The coefficient for capital controls only drops to insignificance when the second lag is used as an instrument, but this is entirely driven by the increase in standard error when moving from OLS to instrumental variables.) Column 3 shows that capital controls are significantly associated with lower investment in authoritarian regimes (at the $90 \%$ level). However, this result does not hold up across either instrumental variables or GMM techniques.

Column 2 shows that the effect of capital controls in democracies remains insignificant with the addition of the investment control. Instrumental variables and both GMM techniques generate the same results with the investment control as without. While OLS and both GMM techniques show that investment is negatively influenced by capital controls in democracies (column 4), this result does not hold up in the instrumental variables specification. Since the latter drop to insignificance is primarily driven by the increase in standard error, we are willing to assign some plausibility to this result. It is conceivable for instance that liberalization of capital flows is more likely to increase investment where such a liberalization is credible, namely in environments with checks and balances that stand in the way of reversal (i.e., in democracies). However, the fact that this does not translate into a significant negative effect for controls on growth is apparent from our core Table 1 regressions where we do not control for this effect. In sum while capital

11 Obstfeld (1998). 


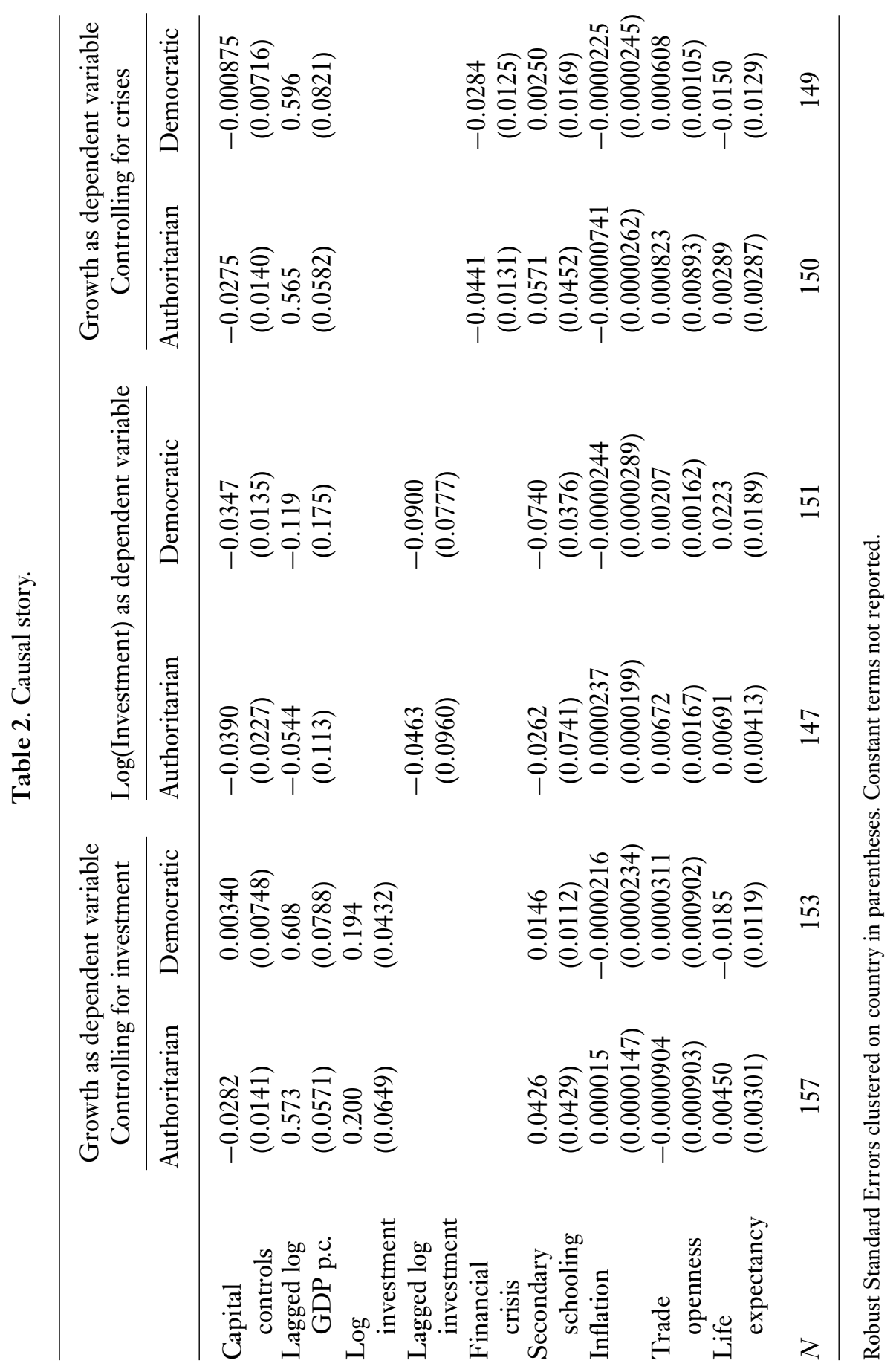


controls may depress investment, support for the idea that the effects of capital controls on growth predominantly pass through the investment channel is ambiguous at best.

This raises the question of whether the effect of capital controls passes through the financial crisis mechanism. Our empirical expectations here are, however, ambiguous. As Kristin Forbes (2004a, p. 2) points out in her review of the capital controls literature "the most frequently cited benefit of capital controls is that they can reduce a country's vulnerability to crises." However, she goes on to add that contrary to the above conventional wisdom most econometric analyses "generally find a positive-instead of negative-correlation between capital controls and the occurrence of currency crises in both bivariate and multivariate analyses" (Forbes 2004a, p. 2). (The implication is that capital controls may generate incentives for bad policies and provide inadequate protection from resulting crises.) Controlling for crises could thus push the effect of capital controls on growth in either direction. Our results are similarly ambiguous. Crises are indeed negatively associated with growth (Table 2, columns 5 and 6). However, both OLS and Blundell and Bond specifications show that even after controlling for financial crises, capital controls continue to have a significant negative effect on growth in authoritarian regimes (column 5). This negative effect drops to insignificance when we use the Arellano and Bond technique along with the crisis control, suggesting that controls may adversely affect growth by increasing the propensity for crises. Indeed, consistent with Forbes' assessment of most of the econometric literature, capital controls are positively correlated with crises in our dataset. (The instrumental variables specification also indicates that the negative effect of capital controls in authoritarian regimes drops to insignificance, but this is driven by the increase in standard error when moving from OLS to instrumental variables; see Table A.3 in the online version of the paper.) As for democracies, all techniques generate the same results with the crisis control as without. (The OLS result is presented in column 6 while the IV and GMM results are in Tables A.3-A.5 in the online version of the paper.) Overall, we are thus unable to conclusively demonstrate that the effects of controls pass through the crisis channel.

Having found ambiguous support for the conventional causal channels emphasized in the theoretical macroeconomics literature we now explore an alternative channel. We start from the fact that the addition of the investment control does not alter the negative effect of capital controls on growth in authoritarian regimes. As Levine and Renelt (1992, p. 946) put it, "if we include investment, the only channel through which the other explanatory variables can explain growth differentials is the efficiency of resource allocation." Thus, the above finding suggests that capital controls may also have microeconomic investment productivity effects.

Kristin Forbes $(2003,2004 a, 2004 b, 2007 a, 2007 b)$ has been at the forefront of a novel research agenda emphasizing the efficiency/productivity costs of capital controls. Forbes observes that "recent work using microeconomic and case study evidence has been much more successful than the macroeconomic literature in documenting the costs of capital controls" (Forbes 2004a, p. 4). She finds that capital controls in Chile made it substantially harder for small firms to raise capital, but not for larger firms, noting that "this inefficient allocation of resources undoubtedly reduced productivity and growth in 
Chile" (Forbes 2004a, p. 4). Aside from Forbes' work on Chile, Simon Johnson and Todd Mitton (2002) have demonstrated a strong relationship between the stock valuation of politically connected firms and the government's greater ability to provide subsidies to these firms under capital controls. In addition, Desai et al. (2004) and Auguste et al. (2002) have emphasized the deadweight costs that are incurred when companies invest resources into evading capital controls. As Forbes puts it, "the bottom line is that a range of compelling microeconomic empirical evidence indicates that capital controls can reduce market discipline and impede overall efficiency" (Forbes 2004a, 2004b, p. 5).

The question for us is: why should we expect these efficiency effects to be more pronounced in authoritarian regimes? To answer this question we look to the political economy literature.

First, Bueno de Mesquita et al. (2003) demonstrate that countries with large winning coalitions (which are primarily democracies) are likely to favor the provision of public goods (goods that benefit the entire citizenry) over the provision of private goods (goods that exclusively benefit members of the winning coalition). In the context of capital controls this implies that authoritarian governments are more likely to use the cover of capital controls to misallocate resources to cronies at the expense of investment productivity.

Second, Acemoglu et al. (2001) show the importance of institutional checks and balances for economic growth. If institutional checks and balances serve to limit misallocations of resources under the cover of capital controls, the differential growth effects of controls in authoritarian and democratic regimes after controlling for investment quantity are consistent with Acemoglu et al.'s causal story.

Finally, Isham et al. (1997) have conducted a cross country study of economic rates of return of government investment projects funded by the World Bank. They find that economic rates of return are positively associated with civil liberties, which are considered indicative of higher public accountability. This implies that democratic governments place a relatively high priority on investment productivity. By implication democracies should be less prone to resource misallocations that depress investment productivity under the cover of capital controls, which is also consistent with our results.

\section{CONCLUSION}

The empirical literature on capital flow liberalization by and large indicates that capital controls are not correlated with economic growth. We present results that differ from this view. We show that while growth in authoritarian regimes is adversely affected by controls, growth in democracies is not affected. We also find that the effects of capital controls likely pass through the investment productivity channel.

Our findings leave some important questions unanswered. The most significant of these relates to the precise causal links in the negative relationship between capital controls and growth in authoritarian regimes when we control for investment. While we provide some theoretical possibilities and cite some cutting edge research, a precise empirical conclusion demands collecting more micro-level data across a much wider range of countries. We consider this to be the logical next step of our research program. 


\section{APPENDIX}

Table A.1. Summary statistics.

\begin{tabular}{lccccc}
\hline Variable & Obs & Mean & Std. Dev. & Min & Max \\
\hline Panel summary statistics & & & & & \\
GDP growth & 318 & 0.0645 & 0.129 & -0.396 & 0.721 \\
Capital controls & 318 & 0.0630 & 1.37 & -2.60 & 1.77 \\
Log GDP p.c. & 318 & 8.47 & 1.05 & 5.72 & 10.3 \\
Democracy & 318 & 0.616 & 0.464 & 0 & 1 \\
Secondary schooling & 318 & 1.50 & 1.14 & 0.0360 & 5.088 \\
Inflation & 318 & 61.5 & 298 & -27.1 & 3360 \\
Trade openness & 318 & 63.6 & 32.5 & 12.9 & 197 \\
Life expectancy & 318 & 65.1 & 10.9 & 34.7 & 80.2 \\
Log(Investment) & 310 & 2.99 & 0.316 & 1.57 & 4.08 \\
Financial crisis & 299 & 0.211 & 0.408 & 0 & 1 \\
& & & & & \\
Cross section summary statistics & & & & & \\
GDP growth & 84 & 0.0151 & 0.0184 & -0.0468 & 0.0587 \\
Capital controls & 84 & -0.159 & 1.09 & -2.60 & 1.72 \\
Democracy & 84 & 0.532 & 0.408 & 0 & 1 \\
Initial period GDP & 84 & 8.11 & 0.953 & 6.10 & 9.71 \\
Secondary schooling & 84 & 1.33 & 1.05 & 0.0701 & 4.469 \\
Inflation & 84 & 62.1 & 190 & -2.05 & 1160 \\
Life expectancy & 84 & 61.8 & 11.2 & 35.6 & 77.7 \\
Trade openness & 84 & 63.1 & 30.0 & 15.5 & 161 \\
Ethnic frag. & 84 & 40.5 & 29.4 & 0 & 90 \\
\hline
\end{tabular}

Table A.2. First stage for instrumental variables results in Table 1.

\begin{tabular}{lcc}
\hline & Authoritarian & Democratic \\
\hline Twice lagged capital controls & -0.288 & -0.194 \\
& $(0.0592)$ & $(0.0351)$ \\
Lagged Log GDP p.c. & -0.0526 & 0.782 \\
& $(0.370)$ & $(0.695)$ \\
Secondary schooling & -0.497 & -0.128 \\
& $(0.339)$ & $(0.103)$ \\
Inflation & -0.0000291 & 0.000295 \\
& $(0.0000556)$ & $(0.000235)$ \\
Trade openness & 0.00293 & -0.00672 \\
& $(0.00544)$ & $(0.00699)$ \\
Life expectancy & 0.00476 & 0.292 \\
& $(0.0244)$ & $(0.0961)$ \\
CD F-stat & 30.34 & 17.57 \\
$N$ & 164 & 154 \\
\hline
\end{tabular}

Robust Standard Errors clustered on country in parentheses. Constant terms not reported. 


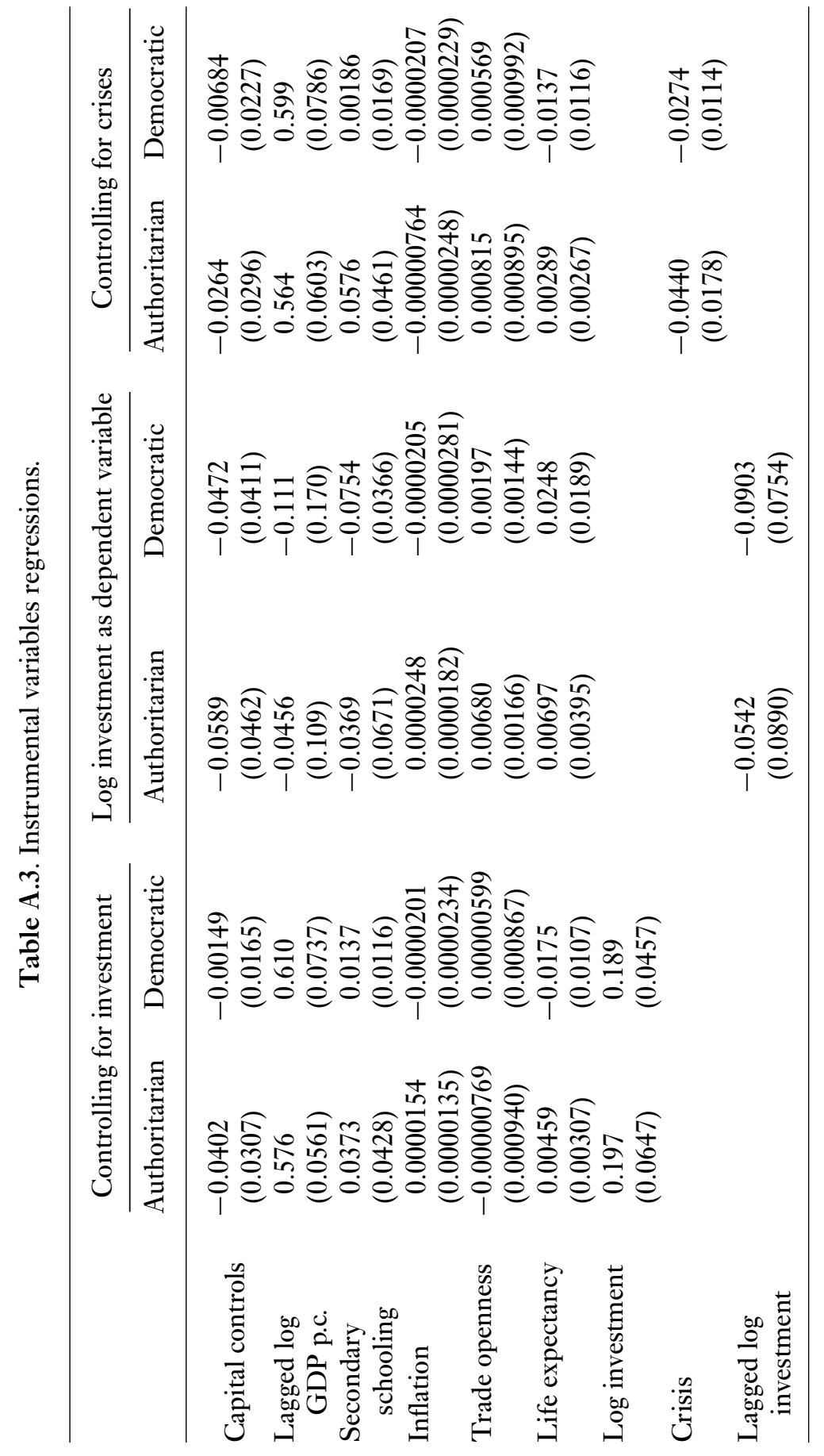




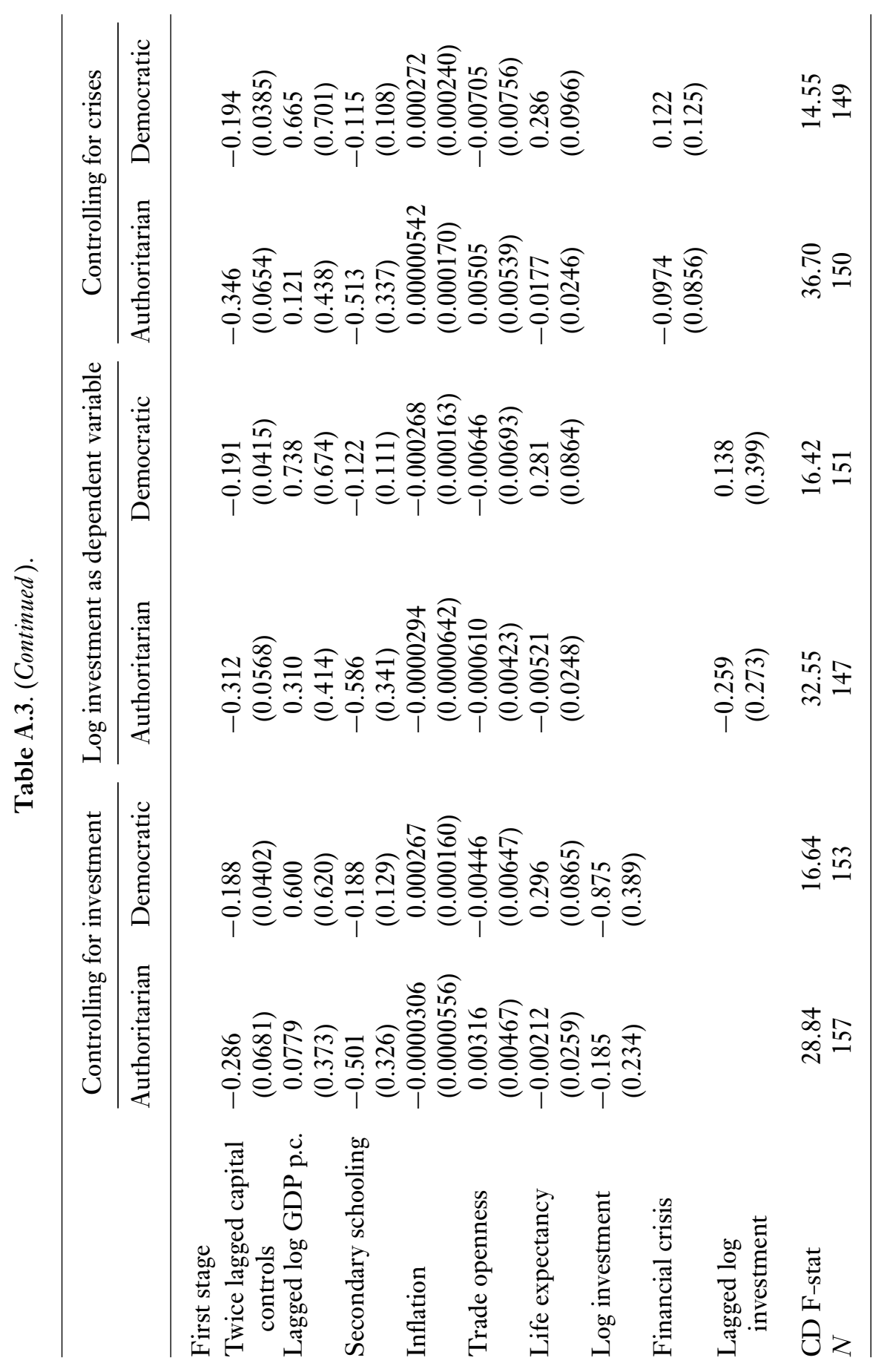




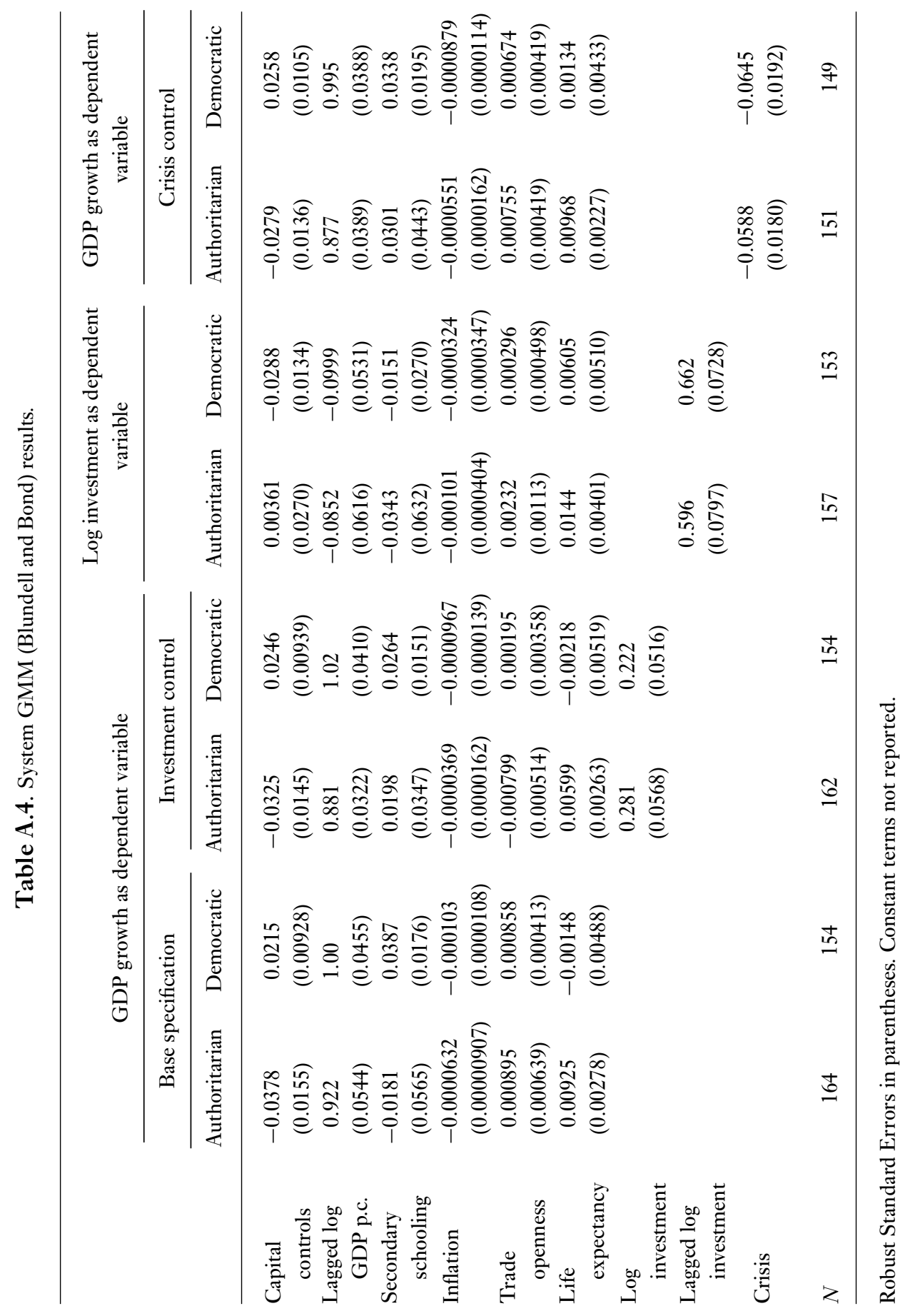




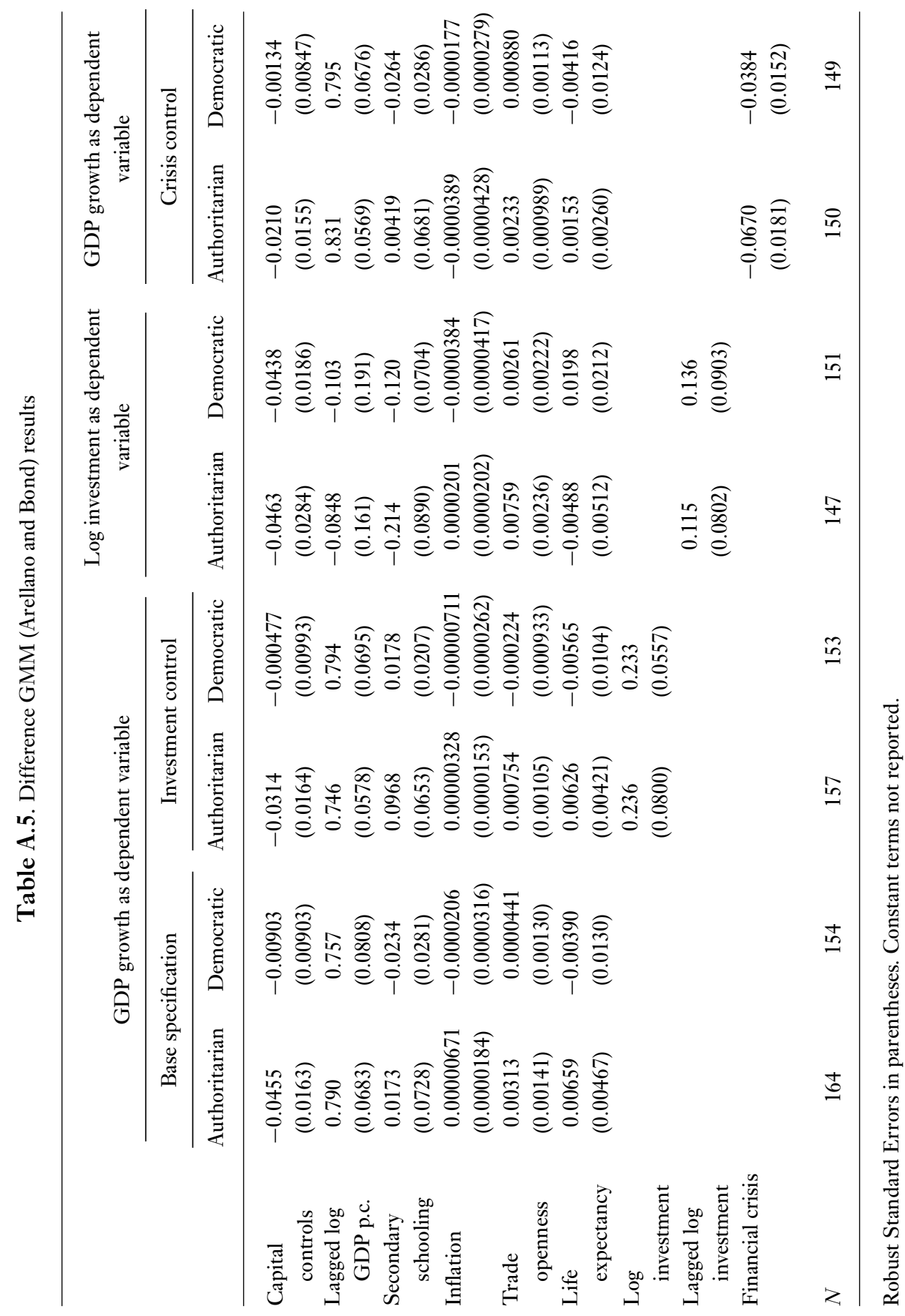




\section{REFERENCES}

Auguste, S., K. Dominguez, H. Kamil, and L. Tesar. 2002. "Cross-Border Trading as a Mechanism for Capital Flight: ADRs and the Argentine Crisis." NBER Working Paper \#9343.

Acemoglu, D., S. Johnson, and J. Robinson. 2001. "The Colonial Origins of Economic Development." American Economic Reviem 91(5): 1369-1401

Alesina, A., V. Grilli, and G. M. Milesi-Ferretti. 1994. "The Political Economy of Capital Controls. In Leiderman, L., and Assaf Razin eds., Capital Mobility: The Impact of Consumption, Investment, and Growth. Cambridge: Cambridge University Press, pp. 289-321.

Alvarez, M., J. Cheibub, F. Limongi, and A. Przeworski. 2000. Democracy and Development: Political Institutions and Material Well Being in the World. New York: Cambridge University Press.

Arellano, M., and S. Bond. 1991. "Some Tests of Specification for Panel Data: Monte Carlo Evidence and an Application to Employment Equations," Reviem of Economic Studies 58(2): 277-297.

Arteta, C., B. Eichengreen, and C. Wyplosz. 2001. "When Does Capital Account Liberalization Help More Than It Hurts?" NBER Working Paper 8414.

Bond, S., A. Hoeffler, and J. Temple. 2001. "GMM Estimation of Empirical Growth Models." Economics Papers 2001-W21, Economics Group, Nuffield College, University of Oxford.

Brambor, T., W. Roberts Clark, and M. Golder. 2005. "Understanding Interaction Models: Improving Empirical Analyses." Political Analysis 14(1): 63-82.

Bueno de Mesquita, B., A. Smith, R. M. Siverson, and J. D. Morrow. 2003. The Logic of Political Survival. Cambridge: MIT Press.

Chinn, M. D. and H. Ito. 2006. "What Matters for Financial Development? Capital Controls, Institutions, and Interactions.” Fournal of Development Economics (forthcoming) and NBER Working Paper 11370, http://www.nber.org/papers/w11370.

Desai, M., C. Fritz Foley, and J. Hines. 2004. "Capital Controls, Liberalizations, and Foreign Direct Investment." NBER Working Paper \#10337.

Easterly, W. and R. Levine. 1997. "Africa's Growth Tragedy: Policies and Ethnic Divisions.” Quarterly Fournal of Economics 112(4): 1203-1250.

Edison, H., M. Kline, L. Antonio Ricci, and T. Slok. 2002. "Capital Account Liberalization and Economic Performance: Survey and Synthesis." IMF Working Paper 02/120, http://www.imf.org/external/pubs/cat/longres.cfm?sk=15912.0.

Edwards, S. 2001. "Capital Flows and Economic Performance: Are Emerging Economies Different?" NBER Working Paper 8076.

Eichengreen, B. and D. Leblang. 2003. "Capital Account Liberalization and Growth: Was Mr. Mahathir Right?” International Fournal of Finance and Economics 8: 205-224.

Forbes, K. 2007a. "One Cost of the Chilean Capital Controls: Increased Financial Constrained for Smaller Traded Firms." Fournal of International Economics 71(2): 291-323.

Forbes, K. 2007b. "The Microeconomic Consequences of Capital Controls: No Free Lunch.” In Sebastian Edwards ed., Capital Controls and Capital Flows in Emerging Economies. Chicago:University of Chicago Press pp. 171-199.

Forbes, K. 2004a. "Mud in the Wheels of Market Efficiency." Presented at the Cato Institute $22^{\text {nd }}$ Annual Monetary Conference, http://www.whitehouse.gov/cea/forbes-cato-talkcapitalcontrols20041104.html

Forbes, K. 2004b. "Capital Controls: Mud in the Wheels of Market Discipline." NBER Working Paper \#10284.

Forbes, K. 2003. "One Cost of the Chilean Capital Controls: Increased Financial Constraints for Smaller Traded Firms." NBER Working Paper \#9777.

Isham, J., D. Kaufman, and L. Pritchett. 1991. "Civil Liberties, Democracy, and the Performance of Government Projects.” World Bank Economic Reviem 11(2): 219-242.

Johnson, S. and T. Mitton. 2002. "Cronyism and Capital Controls: Evidence From Malaysia." Fournal of Financial Economics 67(February): 351-382.

Leblang, D. 2003. "To Defend or Devalue: The Political Economy of Exchange Rate Policy." International Studies Quarterly 47(March): 533-559. 
Levine, R., and D. Renelt. 1992. "A Sensitivity Analysis of Cross Country Growth Regressions." American Economic Reviem 82(4): 942-963.

MacIntyre, A. J. 2002. The Pomer of Institutions: Political Architecture and Governance. Cornell: Cornell University Press.

Nickell, S. M. 1981. "Biases in Dynamic Models with Fixed Effects.” Econometrica 49(6): 1417-1426.

Obstfeld, M. 1998. "The Global Capital Market: Benefactor or Menace?” Fournal of Economic Perspectives 12(4): 9-30.

Pritchett, L. 2000. "Understanding Patterns of Economic Growth: Searching for Hills among Plateaus, Mountains, and Plains." The World Bank Economic Reviem 14(2): 221-250.

Quinn, D. 1997. "The Correlates of Changes in Financial Regulation." American Political Science Reviem 91(3): 531-551.

Rodrik, D. 1998. "Who Needs Capital Account Convertibility?" in Essays in International Finance Vol. 207, Princeton, NJ: Princeton University. 